tree on the crest of the ridge where the Wahiawa-Kahana trail crosses the Koolau Range, July 4th, 1920. This is an extension of the range of this species. It had not previously been taken beyond the ridge on the west side of Nuuanu Valley.

SEPTEMBER 2nd, 1920.

The 180th meeting of the Hawaiian Entomological Society was held at the usual place.

Dr. Williams presided; other members present were Messrs. Giffard, Muir, Ehrhorn, Willard, and Fullaway.

Minutes of the previous meeting were read and approved. Mr. Muir reported on the Scientific Congress in Honolulu.

ENTOMOLOGICAL PROGRAM.

\title{
Recent Observations on Plagithmysus Spp. and Nesotocus Munroi at Kilauea Hawaii (Coleoptera).
}

(With exhibition of specimens)

BY W. M. GIFFARD.

Numerous specimens of Plagithmysus and of Nesotocus munroi were recently collected by the writer during a short summer visit to some of the forest regions at Kilauea, Hawaii. These regions were all within a radius of approximately two and a half miles of the Volcano House, and included areas in the dry, intermediate, and wet forests. In addition are shown several single specimens taken at large and otherwise on previous visits to Kilauea.

Examples of all but the commonest of these will be sent to Dr. R. C. L. Perkins for final determination of the species so that they may, if possible, be added to our reference collections. The exhibit included the following species:

Proc. Haw. Ent. Soc., IV, No. 3, September, 1921. 
Plagithmy'sus darwinianus attached to Sophora chrysophylla.

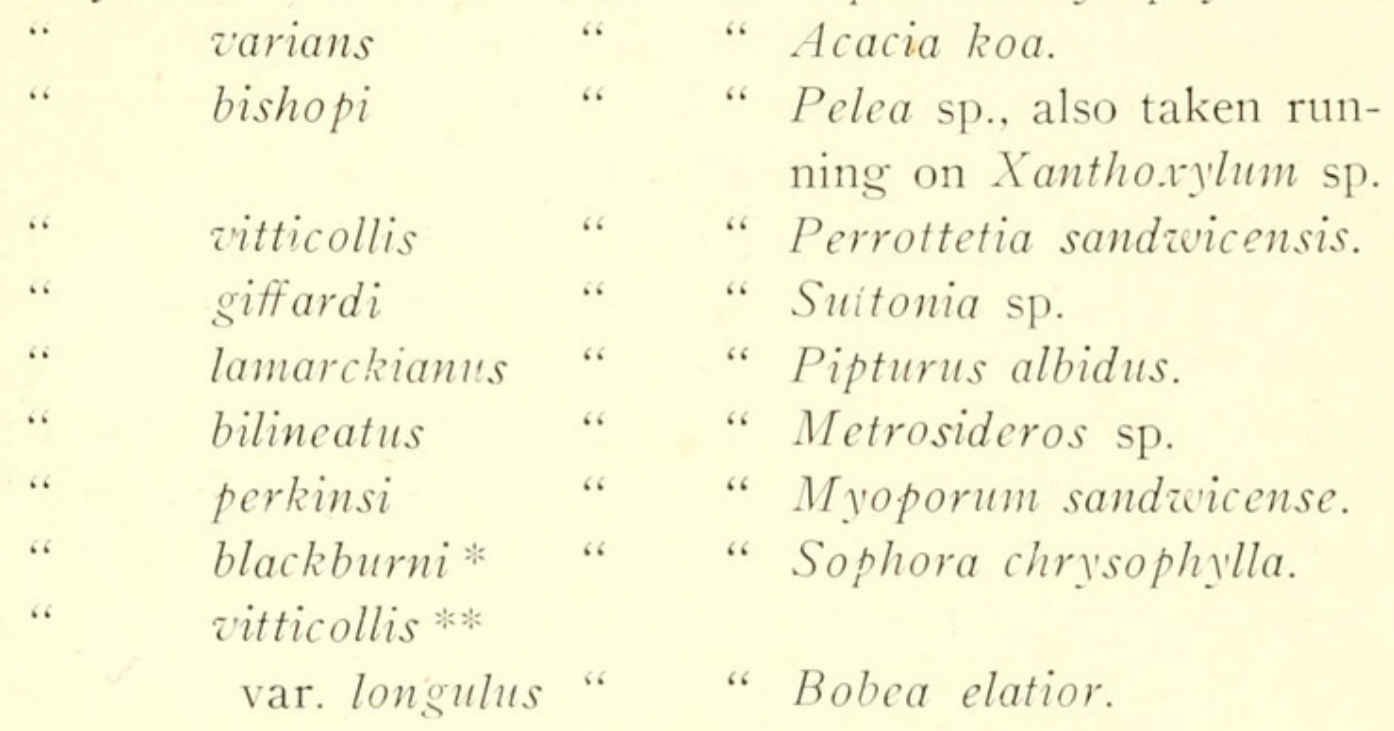

Two very desirable species viz.: $P$. sulphurescens and $P$. vicinus, captured in these forest regions by Dr. Perkins, were not observed and have yet to be re-taken in this and adjacent country. No examples of either of these last-named species are in local collections. P. sulphurescens is said to be attached to a species of Urera, and P. vicimus to a species of Pelea.

While the series of $P$. vitticollis exhibited were undoubtedly attached to a Perrottetia $\rightarrow$ when captured, yet this species has been taken before, somewhere in the neighborhood of Kilauea, on akala (Rubus macraei), and is so recorded. Further observation of Rubus hawaiiensis and Rubus macraei should be made by those who search for our native longicorns in and around Kilauea.

At Kilauea, $P$. varians, $P$. bilineatus, and $P$. darwinianus appear to be the most common of all the species in the region, although most of the others are not uncommon when the trees to which they are attached are found to be in the right condition for attack. Heretofore $P$. perkinsi, $P$. vitticollis, $P$. giffardi, and P. lamarckianus have been found by the writer to be the least abundant in individuals. No doubt the rare $P$. sulphurescens and $P$. vicimus will be taken in similar numbers

* The series of this species was taker: in North Kona. It has not as yet been taken at Kilauea.

** This was taken in the dense wet forest in upper Puna.

$\dagger$ Taken from three trees in dying condition, all near each other. 
when the right tree and region is discovered. P. vitticollis var. longulus so far as learned in previous years from Dr. Perkins, is quite common on Bobea in the dense wet forests of Puna. The few visits made by the writer in this particular region have not been very successful in so far as securing a series of that species. This, perhaps, is due to the large clearings which have been made in that forest region by homesteaders and farmers during late years, as well as to the fact that special search for longicorns has not been attempted by the writer up to the present time. The forests in the Puna region have, for the reason stated above, receded to such an extent as to make them in a large measure almost inaccessible in a day's outing from the Volcano House.

The fact that $P$. blackburni has not, so far as known, been seen or captured in the neighborhood of Kilauea, but only on the Kona slopes of Mauna Loa, and that it is attached, in the latter region, to the same tree as $P$. darwinianus is at Kilauea, is of interest. Perhaps it may be possible to secure some information as to this, as well as to all the other Kilauea species of Plagithmysus, from Dr. Perkins, and also secure from him an example of sulphurescens and of vicinus, both of which are badly needed in our reference collections. The same may be said of certain species from other islands.

The large series of Nesotocus munroi were all taken in the wet forest off Cheirodendron gaudichaudii growing in a recently burned area on a new homestead. The two trees observed were in a scorched and dying condition and in perfect condition for these insects, to which they are well known to be attached. A fair series of extraordinary large males were taken on one of the trees, without females, and the males seen in copula on the other trees were all of the ordinary size. The series represents both sexes about equally. The writer has visited scores and scores of Cheirodendron trees in the neighborhood of the wet forests at Kilauea during recent years, but he never found these attacked by Nesotocus when the tree was in a healthy condition. The same may be said of all trees to which Plagithmysus are attached. 


\section{$2 \mathrm{BHL}$ Biodiversity Heritage Library}

Giffard, Walter M. 1921. "Recent Observations on Plagithmysus Spp. And Nesotocus Munroi at Kilauea Hawaii (Coleoptera)." Proceedings of the Hawaiian Entomological Society 4, 490-492.

https://doi.org/10.5962/bhl.part.16152.

View This Item Online: https://www.biodiversitylibrary.org/item/39842

DOI: https://doi.org/10.5962/bhl.part.16152

Permalink: https://www.biodiversitylibrary.org/partpdf/16152

\section{Holding Institution}

Smithsonian Libraries

\section{Sponsored by}

Smithsonian

\section{Copyright \& Reuse}

Copyright Status: NOT_IN_COPYRIGHT

This document was created from content at the Biodiversity Heritage Library, the world's largest open access digital library for biodiversity literature and archives. Visit BHL at https://www.biodiversitylibrary.org. 